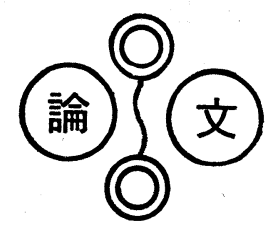

\section{石炭液化初期過程における水素移動}

\author{
-1982. 11. 1 受理一
}

\section{1. 緒音}

$650 \mathrm{~K}$ 以上の温度に括ける石炭の水添液化反応は熱 分解反応による活性なフリーラジカルの生成により開 始する。このフリーラジカルが，互いに再結合して巨 大分子として安定化する前に, 水素によって安定化さ れると,プレアスファルテン（ピリジン可溶一ベンゼ ソ不溶分),アスファルテン (ベンゼン可溶一n一ヘキサ ン不溶分)，オイル(n一ヘキサシ்可溶分）执よびガスな どの低分子化合物が得られる。液化反応の初期に拉い ては, オイルとガスの生成速度はアスファルテンのそ れと比較すると急速であるが，反応の進行とともに次 第に遅くなり，一般に，石炭をベンゼン不溶分とした 総括反応速度は, 時間とともに減少して一定值に近づ く1。このような液化反応の特性を説明するために, 著者ら 2 は石炭が反応性の異なる 2 つの反応種から構 成されると考えた反応モデルを提出した。すなわち, 一方（Coal 1）はアスファルテンを経由した比較的緩 慢なオイル生成に寄与する成分であり，他方(Coal 2) は活性が高く, 水素消費をほとんど伴わずに反応初期 の急速なオイルおよびガス生成に寄与する成分 ${ }^{334}$ で ある。

一方, フリーラジカルを安定化させる水素に注目し た場合，Fig.1に示すように，水素供与性をるつ成分

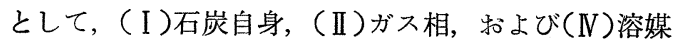
の 3 つが考兄られるこれらの水素は, さらに, (II') 生成液化油の水素化扰よび水素化分解や (III)水素供与 性溶媒の再生にも消費される。石炭自身からの水素移 動( I ) は, Neavel ${ }^{5)}$ によって反応初期のピリジン可溶 分収率が溶媒に水素供与性のテトラリンを用いても非 供与性のナフタレンを用いても0.85～0.95の高い収率 を得る実験事実を説明するために示唆された。また， Whitehurst $ら^{6)}$ および Gorin $5^{9)}$ 窒素雾团気で非水 素供与性溶媒を用いた場合，反応初期（約 3 分）にそ

工学部石炭研究室 札幌市北区北13条西8丁目
の収率が約0.50亿達することを観測している。このよ 万な結果は, 石炭中の水素が水素供与性と受容性を併 せるつ溶媒分子の助けにより移動するという “シャト リング”機構により良く説明される。しかしながら Whitehurst $5^{6) \sim 87}$ および Longanbach $ら^{10)}$ は, 反 応初期の石炭の反応率が反応後期同様, 水素压力や溶 媒中のテトラリン濃度に依存し ${ }^{711112)}$, Neavel ${ }^{5)}$ の結 果と異なることを報告している。これは，シャトリン グ機構による水素移動ばかりでなく, ガスめるいは溶 媒中に溶解した氷素 (以下直接移動 (II)), あるいは 水素供与性溶媒からの水素(以下ドネーション(IV))の 寄与を示唆している。

また，液化反応に対する溶媒と触媒の効果について る異なった解釈が試みられている。通常, 触媒は消費 された水素供与性溶媒の溶解水素による水添, 再生(以

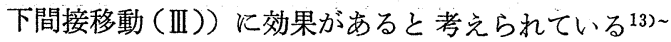
17)。それに対し，最近 Uedaら ${ }^{18}$ は，石炭のベンゼン 可溶分への反応率が溶媒の水素供与性とは無関係なこ とを示す実測結果を得ている。すなわち，多くの溶媒 について得られた反応率は触媒を用いない場合には， 反応時間 20 分あるいは60分で，0.70 0.80であり，触 媒を用いた場合には0.90〜1.00であって，いずれの場 合にも反応率が溶媒の水素供与性には依存しない。彼 らは，これらの結果から，溶媒は石炭粒子の分散と水 素の溶解を促進するが，（N）以上る水素移動への笴与 をほとんどもたず，また触媒は石炭拈よび液化油の気 相あるいは溶解水素による水素化执よび水素化分解を 助長すると推断した。

このように, 従来の多くの石炭液化反応に関する研 究に扣いては, 反応の後期あるいは初期の特定の水素 移動過程だけが強調されてきた。また触媒効果につい ても気相水素の直接移動飞効くのか, 間接移動飞効く のかは議論のあるところである。とくに液状中間生成 物からオイル分へと水素化される後期過程と固体状に 


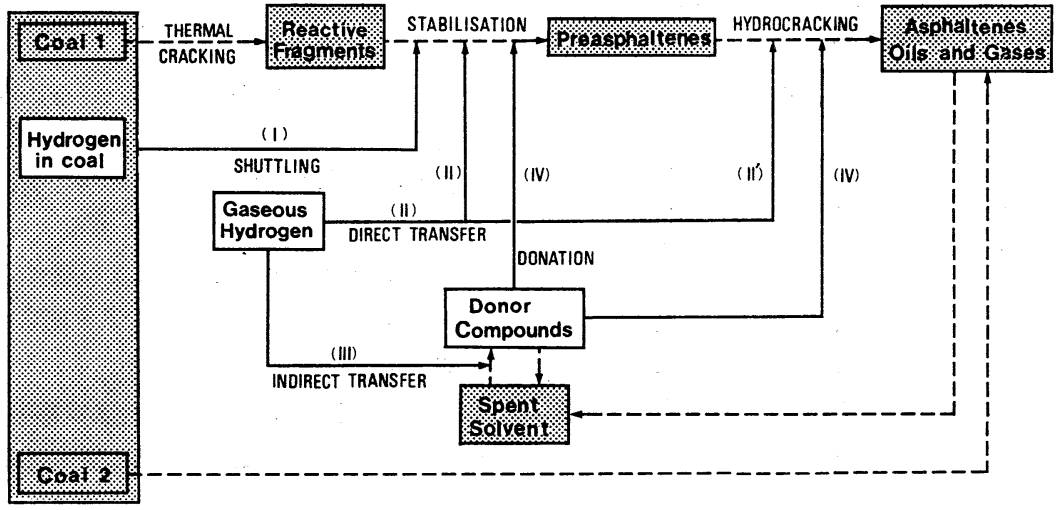

Fig. 1 A possible mechanism of hydrogen transfer in coal liquefaction

近い石炭が低分子化される初期過程とでは異なる触媒 作用が存在すると考えられる。本研究では，これまで 提案されてきた各水素移動過程や触媒作用を Fig.1 に 示す反応機構モデルに基づき，それぞれの液化反応に 与える寄与を定量的に評価することを目的としてい る。すなわち，単純化された反応系をも含む一連の液 化反応実験を組織的に行うことにより，とくに，液化 反応初期過程での水素移動過程と溶媒抽よび触媒の効 果について検討した。

\section{2. 実験}

\section{1 実験装置}

実験で使用した急速昇温小型オートクレーブ反応装 置を Fig. 2 に示す。オートクレーブは電磁攪䢁式で, 内容積は $27 \mathrm{~cm}^{3}$ であり，250 $\mathrm{cm}^{3}$ の圧力緩衝容器に連結し て，反応中に圧力が一定に保たれるように工夫されて いる。オートクレーブの加熱には赤外線イメージ炉を

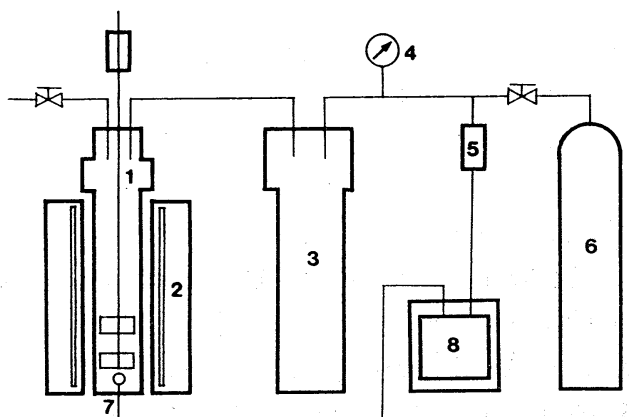
1 Micro-autoclave $\left[27 \mathrm{~cm}^{3}\right]$
5 Pressure transducer
2 Infrared image furnace
6 Gas cylinder
3 Buffer vessel $\left[250 \mathrm{~cm}^{3}\right.$ ]
4 Pressure gauge
8 Recorder

Fig. 2 Schematic diagram of micro-autoclave system
用いた。昇温速度は, 本実験のような回分式反応器に よる実測値を流通式反応器の解析に用いる際に重要な 因子のひとつとなる ${ }^{19}$ が，ここでは流通式反応器の場 合とほぼ同等の速度である $150 \mathrm{~K} / \mathrm{min}$ で急速昇温し た。一定温度保持後の冷却は圧搾空気の吹き付けによ り $100 \mathrm{~K} / \mathrm{min}$ の速度で行った。

\section{2 試 料}

実験では 100 メッシュ以下に粉碎した太平洋炭を主 試料炭とした。また，この比較試料炭としてイリノイ No. 6 (Peabody) 炭を同様に粉碎して用いた。溶媒に は, 水素供与性溶媒としてテトラリン, 非供与性溶媒 としてナフタレンを，さらに一部の実験にはこれらの 混合溶媒を用いた。触媒としては，硫黄を助触媒とし

Table 1 Properties of coals used

\begin{tabular}{lcc}
\hline & Taiheiyo & $\begin{array}{c}\text { Illinois No.6 } \\
\text { (Peabody) }\end{array}$ \\
\hline Ultimate analysis & [wt\% & daf coal] \\
Carbon & 78.7 & 68.2 \\
Hydrogen & 6.3 & 5.0 \\
Oxygen & 13.7 & 21.4 \\
Sulphur & 0.1 & 4.0 \\
Nitrogen & 1.2 & 1.4 \\
\hline Proximate analysis & {$[\mathrm{wt} \%$ mf coal] } \\
Volatile matter & 52.8 & 42.2 \\
Fixed carbon & 36.8 & 46.6 \\
Ash & 11.2 & 11.2 \\
\hline Maceral & {$[\mathrm{vol} \%$ af coal] } \\
Vitrinite & 83 & 87 \\
Exinite & 13 & 5 \\
Fusinite & 1 & 3 \\
Micrinite & 3 & 5 \\
\hline
\end{tabular}


Table 2 Chemical composition of red-mud catalyst and coal ashes

red-mud Taiheiyo Illinois No.6

\begin{tabular}{|c|c|c|c|}
\hline $\mathrm{SiO}_{2}(\%)$ & 13. 14 & 50.37 & 59.26 \\
\hline $\mathrm{Al}_{2} \mathrm{O}_{3}(\%)$ & 19.72 & 27.24 & 25.33 \\
\hline $\mathrm{Fe}_{2} \mathrm{O}_{3}(\%)$ & 41.06 & 4.04 & 16.60 \\
\hline $\mathrm{TiO}_{2}(\%)$ & 6.24 & 1.22 & 1.07 \\
\hline $\mathrm{CaO}(\%)$ & 2.13 & 9.88 & 6.11 \\
\hline $\mathrm{MgO}(\%)$ & - & 2.02 & $(0.33)$ \\
\hline $\mathrm{Na}_{2} \mathrm{O}(\%)$ & 8.25 & 0.73 & 0.77 \\
\hline $\mathrm{K}_{2} \mathrm{O} \quad(\%)$ & - & 0.94 & 1.48 \\
\hline $\mathrm{P}_{2} \mathrm{O}_{5}(\%)$ & - & 0.73 & 0.10 \\
\hline
\end{tabular}

た赤泥と市販 Co-Mo（トリローブHD S-20）触媒を 使用した。試料炭の元素分析，工業分析およびマセラ ル分析結果を Table 1 に，また，石炭灰および赤泥触 媒の組成分析結果を Table 2 に示す。

\section{3 実験操作}

各実験に和ける 乾燥試料炭の充媜重量は $3.0 \mathrm{~g}$ であ る。溶媒を用いる場合には $7.0 \mathrm{~g}$ を充填し，溶媒を用 いない（以下無溶媒）場合には，石炭粒子を分散させ るために，2.0gのー60+80メッシュのガラスビーズ を石炭粒子とできるだけ均一に混合して用いた。さら に触媒を用いる場合にはその充媜重量を $0.33 \mathrm{~g}$ とし た。これらを充填した後，反応系をあらかじめ窒素あ るいはへリウムガスでパージした上で，水素あるいは 窒素ガスを所定の圧力まで充埧した。次いで反応器を 上述の速度で急速昇温し，一定反応温度に達してから 所定の時間（見掛け反応時間）後，冷却した。ここで 報告する実験結果は $723 \mathrm{~K}, 10.1 \mathrm{MPa}$ の温度および圧 力に拈いて得られたるのである。

\section{4 分 析}

反応後，得られた試料を，まずベンゼン中で 3 時間 煮沸抽出し，ろ過した。不溶残渣をさらにベンゼンで 繰返し洗浄した後，得られた残渣をろ別，一昼夜減圧 乾燥して科量した。得られたベンゼン不溶分を同様の 操作でピリジン抽出し，ピリジン不溶分を得た。これ らの測定に基づいてピリジンおよびベンゼン可溶分の 収率 yPS 乱よび y BSを無水，無灰基準（d.a.f.）で定 義した。

$$
\begin{aligned}
& y_{P S}=1-\frac{[\text { d.a.f. PI }]}{[\text { d.a.f. C }]} \\
& y_{B S}=1-\frac{[\text { d.a.f. BI }]}{[\text { d.a.f.C }]} \\
& \text { こで, } \\
& \text { PI : ピリジン不溶分重量 }
\end{aligned}
$$

\section{BI：ベンゼン不溶分重量 \\ C : 石炭重量}

である。なお，触媒を使用した場合には，触媒の反応 前後による重量変化がないものとし，ピリジン不溶分 重量から触媒の充填重量分だけ差し引いてPIとした。

\section{3. 結果と考察}

ここで報告する結果を得た実験条件と見掛け反応時 間30分に和けるピリジンおよびベンゼン可溶分収率を 一括して Table 3 亿示す。

\section{1 触媒を用いない場合の水素移動}

前述のように，触媒の有無によって水素移動が異な ることについて確かめるため，まず，触媒を用いない （以下無触媒）場合に関する一連の結果を示す。Fig. 3 は太平洋炭について窒素雰囲気下で得られたピリジン 可溶分収率 $\mathrm{y}_{\mathrm{PS}}$ の経時変化をまとめたものである。図 中，ピリジン抽出(i)とあるのは原炭を $388 \mathrm{~K}$ に和いて 所定時間ピリジン抽出して得られた結果である。Fig. 1 の反応機構モデルで, Coal 2 と定義されるものはピ リジン不溶分であり，中間生成物拉よび最終生成物は ピリジン可溶分であることから，原炭のもつピリジン 可溶分(i)は, Coal 1 およびその反応経路から除去し, Coal 2 に包含される成分として各水素移動過程の y PS への寄与を評価した。無溶媒の場合(ii)，溶媒としてナ フタレン(iii)和よびテトラリン(iv)を用いた場合，いずれ の場合にも収率は反応開始後急激に増加した後，ほぼ 一定值（以下最終収率）となっている。(ii)および(iii)の 場合の最終収率はそれぞれ0.35と0.40で，両者の差は 小さい。これらの場合にはガス相 (II) 抽よび溶媒 (IV) からの水素移動はないので，yPS 性素消費を伴わな いCoal 2 からの生成々分とシャトリング（I）だけに よる Coal 1 からの生成々分とから構成されると考㐫 られる。しかし(i)を除く(ii)和よび(iii)の yPS は，0.30〜 0.35 であり，Coal 2 からの生成々分を含めてシャト リングによる水素移動としても，あまり高い収率では ない。また，溶媒（ナフタレン）による石炭粒子の分 散効果がシャトリングに及ぼす影響は小さいとい兄 る。それに対し，テトラリン(iv)の場合にはシャトリン グ（I ）ばかりでなくドネーション (N)の寄与も加わる ので，反応時間が10～15分で0.90以上の高い最終収率 が得られている。この場合の収率に対するシャトリン グの寄与率 [=(yps(iii) - yps(i))/yps(iv) $]$ は反応時間が 0 分で約 $63 \%$ と最も高く，時間とともに減少して最終 収率が得られる時間には約 $43 \%$ となる。

同様の実験を水素雾囲気下で行ったときの yPS と y Bs の経時変化をFig.4(a), (b) に示す。破線は Fig.3の 
Table 3 Experimental conditions and yields observed at nominal reaction time of $30 \mathrm{~min}$.

Reaction temperature ; $723 \mathrm{~K}$

Reaction pressure ; 10.1MPa

\begin{tabular}{|c|c|c|c|c|c|c|c|}
\hline \multirow[b]{2}{*}{ Run No. } & \multirow[b]{2}{*}{ Coal } & \multicolumn{2}{|c|}{ Solvent } & \multirow[b]{2}{*}{ Gas } & \multirow[b]{2}{*}{ Cat. } & \multirow[b]{2}{*}{$\begin{array}{c}\text { yPs } \\
{[-]}\end{array}$} & \multirow[b]{2}{*}{$\begin{array}{c}\mathrm{y}_{\text {BS }} \\
{[-]}\end{array}$} \\
\hline & & $\left.\begin{array}{c}\mathrm{T} \\
{[\mathrm{g}}\end{array}\right]$ & $\begin{array}{c}\mathrm{N} \\
{[\mathbf{g}]}\end{array}$ & & & & \\
\hline 1 & Taiheiyo & 0 & 0 & $\mathrm{~N}_{2}$ & - & 0.355 & 0.343 \\
\hline 2 & & 0 & 0 & $\mathrm{H}_{2}$ & - & 0.407 & 0.354 \\
\hline 3 & & 0 & 7 & $\mathrm{~N}_{2}$ & - & 0.410 & 0.361 \\
\hline 4 & & 0 & 7 & $\mathrm{H}_{2}$ & - & 0.472 & 0.387 \\
\hline 5 & & 7 & 0 & $\mathrm{~N}_{2}$ & - & 0.910 & 0.721 \\
\hline 6 & & 7 & 0 & $\mathrm{H}_{2}$ & - & 0.916 & 0.792 \\
\hline 7 & & 1 & 6 & $\mathrm{~N}_{2}$ & - & 0.634 & 0.505 \\
\hline 8 & & 1 & 6 & $\mathrm{H}_{2}$ & - & 0.752 & 0.587 \\
\hline 9 & & 2 & 5 & $\mathrm{H}_{2}$ & - & 0.839 & 0.616 \\
\hline 10 & & 1 & 0 & $\mathrm{H}_{2}$ & - & 0.663 & 0.501 \\
\hline 11 & & 2 & 0 & $\mathrm{H}_{2}$ & - & 0.888 & 0.722 \\
\hline 12 & & 3 & 0 & $\mathrm{H}_{2}$ & - & 0.921 & 0.737 \\
\hline 13 & & 5 & 0 & $\mathrm{H}_{2}$ & - & 0.909 & 0.762 \\
\hline 14 & & 0 & 0 & $\mathrm{H}_{2}$ & $\mathrm{RM}$ & 0.610 & 0.533 \\
\hline 15 & & 0 & 7 & $\mathrm{~N}_{2}$ & $\mathrm{RM}$ & 0.410 & 0.361 \\
\hline 16 & & 7 & 0 & $\mathrm{~N}_{2}$ & $\mathrm{RM}$ & 0.969 & 0.740 \\
\hline 17 & & 7 & 0 & $\mathrm{~N}_{2}$ & $\mathrm{CM}$ & $0.832^{*}$ & $0.683^{*}$ \\
\hline 18 & & 0 & 7 & $\mathrm{H}_{2}$ & RM & 0.903 & 0.699 \\
\hline 19 & & 7 & 0 & $\mathrm{H}_{2}$ & $\mathrm{RM}$ & 0.942 & 0.786 \\
\hline 20 & Illinois No. 6 & 0 & 7 & $\mathrm{~N}_{2}$ & - & 0.321 & 0.265 \\
\hline 21 & & 0 & 7 & $\mathrm{H}_{2}$ & - & 0.738 & 0.556 \\
\hline 22 & & 7 & 0 & $\mathrm{H}_{2}$ & - & 0.929 & 0.698 \\
\hline
\end{tabular}

$\mathrm{T}$; Tetralin, $\mathrm{N}$; Naphthalene, RM ; Red-mud, CM ; Co-Mo * at $15 \mathrm{~min}$

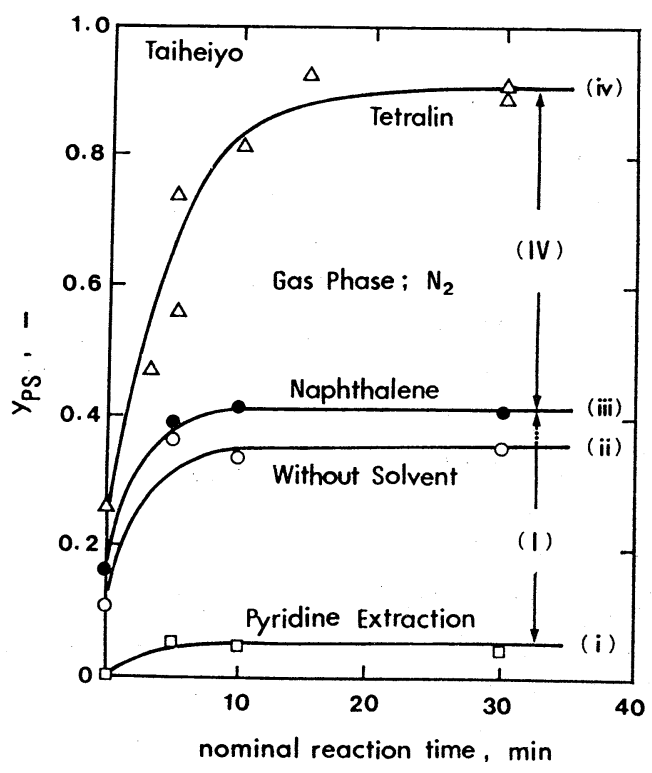

Fig. 3 Yields of pyridine solubles at nitrogen pressure of $10.1 \mathrm{MPa}$ and $723 \mathrm{~K}$
窒素雾囲気下での結果である。図から水素雰团気下で も無溶媒持よびナフタレンを用いた場合の収率は小さ いことがわかる。この結果, 溶媒による石炭粒子の分 散効果はシャトリング（I）ばかりでなく直接移動( II ) に対しても大きな影響を及ぼさないといってよい。ま た，水素供与性溶媒であるテトラリンを用いた場合の YPS 特よび y BS の收率はガス雰囲気にまったく依存 しないのに対し, 無溶媒およびナフタレンの場合には 水素雰囲気の方が反応の進行に伴い僅かに高い収率と なる傾向が認められる。もし，このガス雰囲気の違い による収率の差が，灰分の弱い触媒作用 ${ }^{14}$ による水素 の直接移動( II) あるいは液化生成物を含む溶媒を経由 する間接移動(III)の寄与によってもたらされたものと すると，石炭や灰分の組成の異なる試料について異な った収率の差が得られることが予想される。そこで， イリノイ炭を試料として，この点を検討した。その結 果, Fig. 5 に示すように，太平洋炭とはかなり異なっ た反応特性を示す。すなわ，イリノイ炭の場合, 反応進行とともにガス雰囲気による差が顕著になる。 


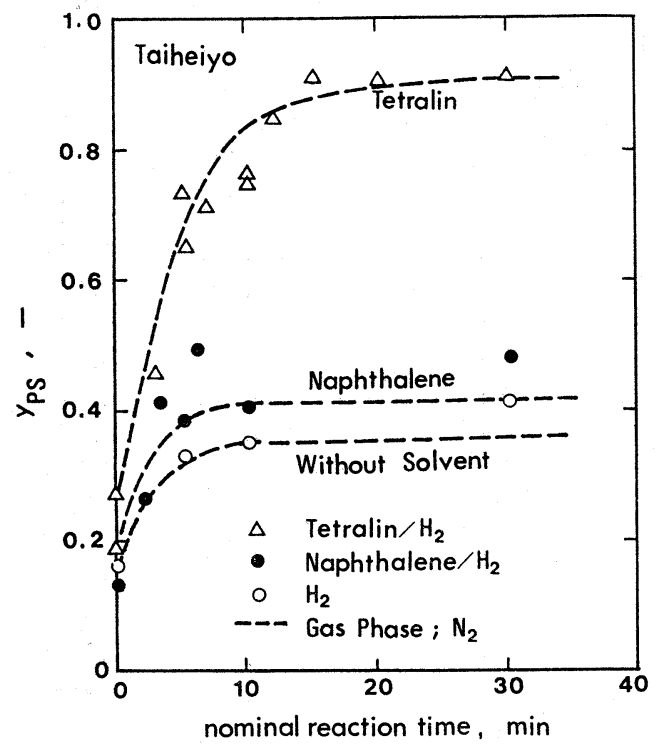

Fig. 4 (a) Effect of hydrogen gas on pyridine solubles yields at $10.1 \mathrm{MPa}$ and 723K

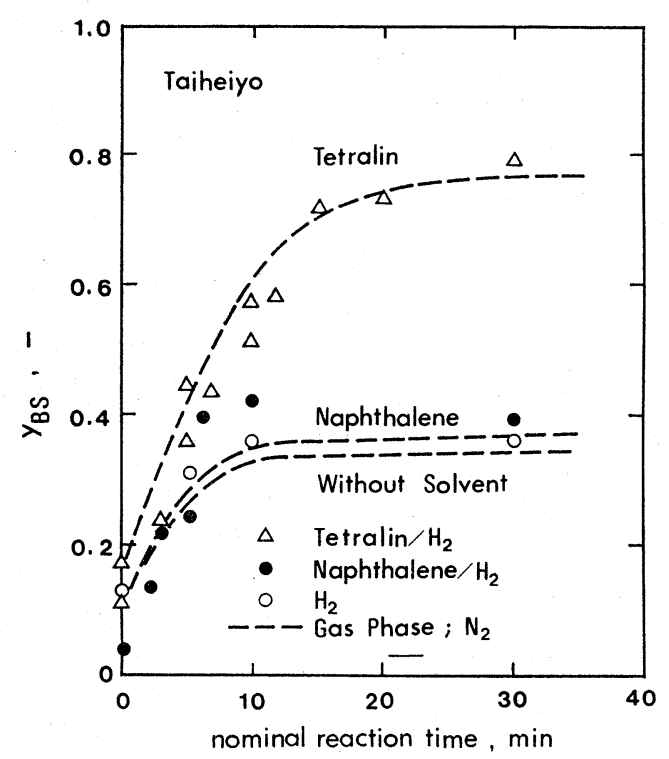

Fig. 4 (b) Effect of hydrogen gas on benzene solubles yields at $10.1 \mathrm{MPa}$ and 723K

ナフタレン/水素系(iii)において y PS が反応時間ととも に増加するのは, イリノイ炭中の灰分（とくに硫化鉄 系化合物）が水素の直接あるいは間接移動に触媒作用 を示す15)ものとすれば十分説明でき，究極的には(iii)の 最終収率は (iv)のそれに近づくものと考えられる。ま

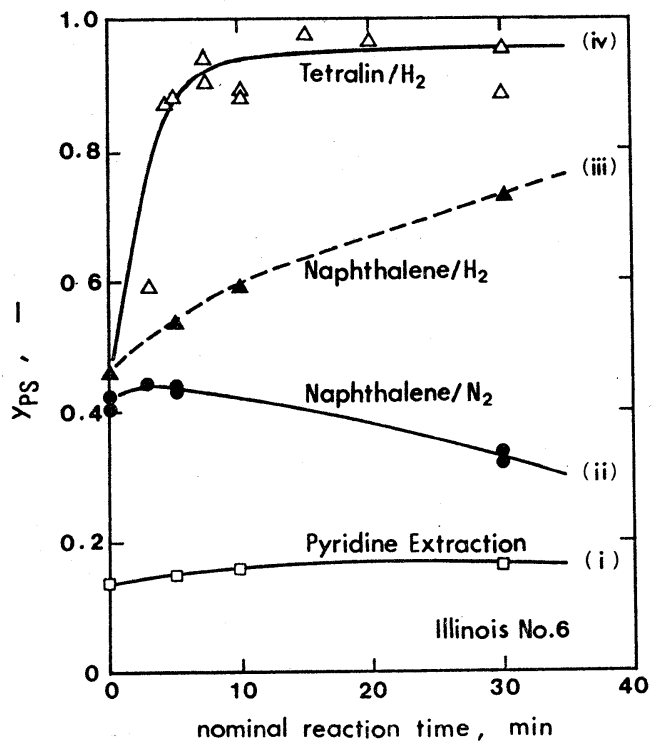

Fig. 5 Yields of pyridine solubles of Illinois No. 6 coal at $10.1 \mathrm{MPa}$ and $723 \mathrm{~K}$

た，この石炭は太平洋炭と比べて Coal 2 の割合(i)が 大きく,ナフタレン/窒素系(ii)では, 約 5 分以後収率 は時間とともに次第に減少するので, シャトリング （I）の寄与率は 0，5，30 分でそれぞれ 88，40，21\% と急激に減少する。このように石炭によって差があら われる原因については現状では不明であるが，いずれ にしても上記のシャトリング寄与率を炭種評価のため の重要なパラメータのひとつとして用いることができ よう。

一方,ドネーション(IN)の寄与についてナフタレン, テトラリンの混合溶媒を用いて検討した。太平洋炭の 場合の結果をFig.6に示す。ピリジン可溶分の収率は溶 媒中のテトラリン濃度とともに増加するが，それとと もに, 濃度に対する収率の増加割合は減少する。また, この図よりテトラリン/ナフタレン重量比が $1 \mathrm{~g} / 6 \mathrm{~g}$ のとさにガス雾囲気に対する y PS の経時変化を調べて みたところ, $0 \mathrm{~g} / 7 \mathrm{~g}$ の場合 (Fig.4 (b)) と同様, 水素 雾囲気の方が窒素雾囲気よりも大きめの值を示し，テ トラリン濃度が低いときには，ガス相水素の移動（II あるいはIII）の影響がわずかにあることがわかる。さ らに, yPs に対するガス相からの水素移動の寄与より もテトラリンによる寄与の方が大きいことを明らかに するために，溶媒の石炭粒子分散効果が小さいことか ら，石炭 $3 \mathrm{~g}$ に対してテトラリンだけを種々の重量で 用いた場合の収率を比較してみた。その結果をFig. 7 
に示す。図からピリジンおよびベンゼン可溶分の収率 はテトラリン重量が 0 ～ $2 \mathrm{~g}$ までの間に急激に増加して いることがわかる。また，テトラリンをこれ以上に増 すとベンゼン可溶分の収率は僅かに増すが，等量以上

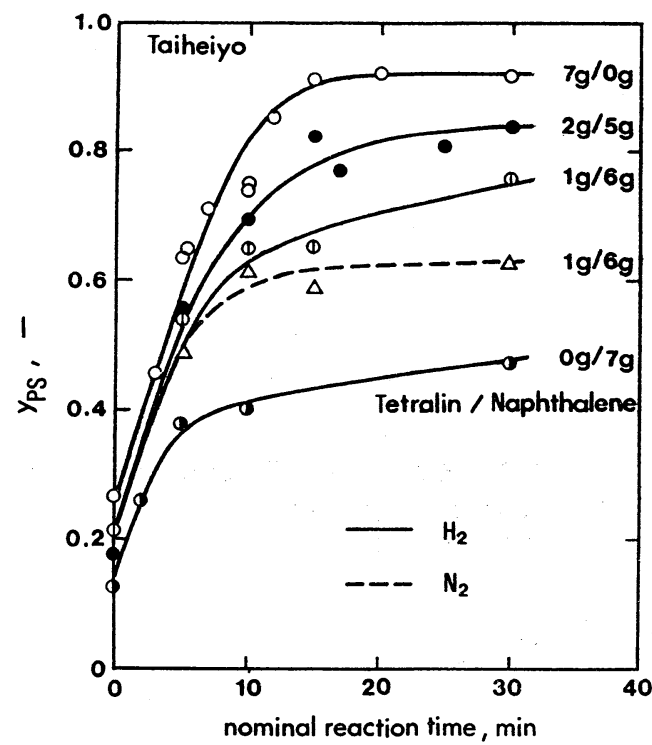

Fig. 6 Effect of tetralin concentration on rate of pyridine solubles formation at 10. $1 \mathrm{MPa}$ and $723 \mathrm{~K}$

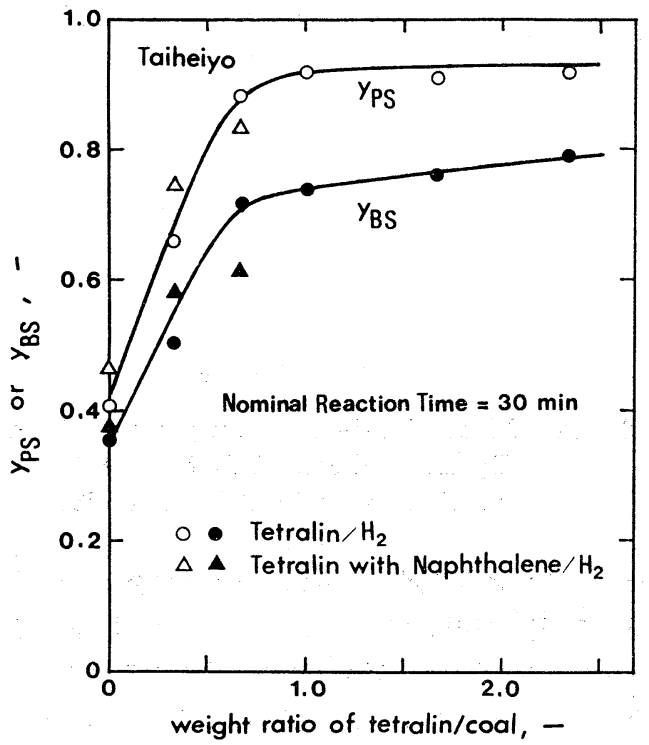

Fig. 7 Effect of weight ratio of tetralin to coal on yields of pyridine and benzene solubles at $10.1 \mathrm{MPa}$ and $723 \mathrm{~K}$
ではピリジン可溶分収率はほとんど変化しないことが わかる。

\section{2 触媒存在下に打ける水素移動}

Fig. 8 は，触媒として赤泥を用いたときの太平洋炭 について得られた収率の経時変化を示したものであ る。図から明らかなように，無触媒の場合（破線）とほ ぼ同一の収率が得られている。この場合, ナフタレン と窒素を用いているので，考え得る水素移動はシャト リング（Ｉ）だけであり，この結果はシャトリングに対 する触媒効果がないことを示している。また，ナフタ レンのかわりにテトラリンを用いてドネーション(N) に対する触媒の効果を検討したのが Fig.9 である。赤

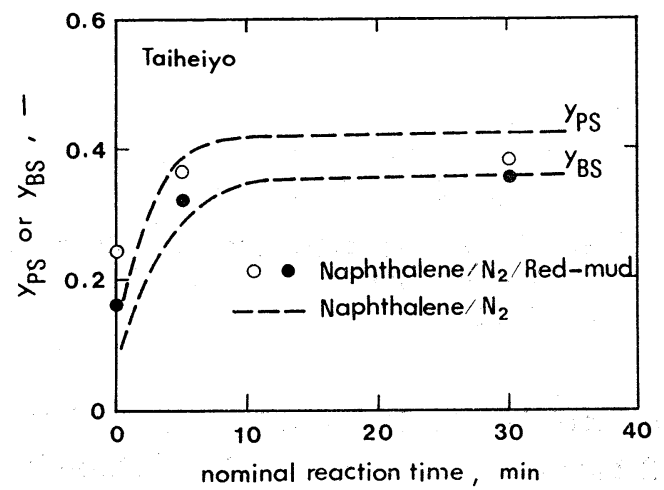

Fig. 8 Effect of red-mud catalyst on "shuttling (I )" at nitrogen pressure of $10.1 \mathrm{MPa}$ and $723 \mathrm{~K}$

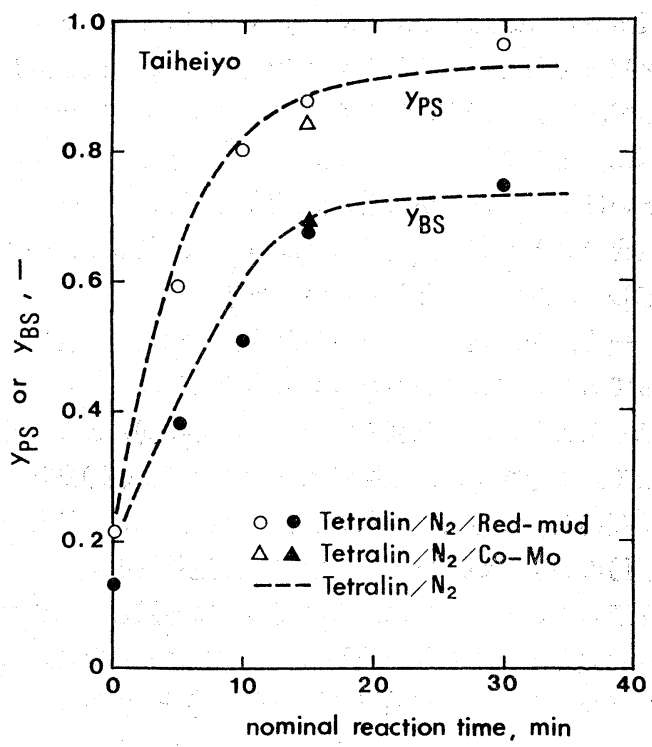

Fig. 9 Effect of catalysts on "donation (IV)" at nitrogen pressure of $10.1 \mathrm{MPa}$ and 723K 


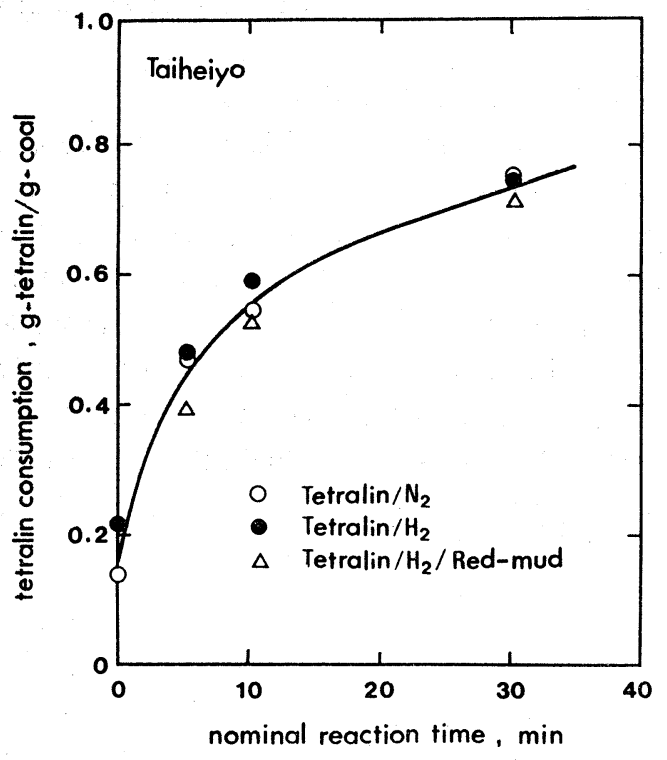

Fig. 10 Effect of hydrogen gas and catalyst on tetralin consumption at $10.1 \mathrm{MPa}$ and 723K

泥および Co-Mo 両触媒の場合とも収率は無触媒の場 合と変わらず，ドネーションに対する触媒効果もない といえる。このように溶媒として水素供与性をもつテ トラリンを十分に用いると，ガス雰囲気の影響も触媒 の影響むほとんど受けない。この点をテトラリンの消 費量からも確認するために，ガスクロによりテトラリ ン残量を測定し，テトラリンの分解による消失を無視 して, 石炭 $1 \mathrm{~g}$ 当たりのテトラリン消費重量を求めて みた。その結果がFig.10であり，ガス雾团気が窒素あ るいは水素, および水素と赤泥触媒を用いたすべての 場合でテトラリン消費量はほぼ等しく, 収率変化に対 応して増加することが明らかである。

一方, 無溶媒で水素を用いた場合, 触某の存在によ ってピリジン怙よびベンゼン可溶分収率は，Fig.11に 示したよらに，無触媒の場合 (Fig.4(a), (b)) より高く なる。この結果は，触媒が水素ガスの直接(II)あるい は反応初期に生成した液化生成物を介した間接移動 （III）のいずれか，あるいは両方に促進効果をもつこと を示している。さらに，この反応系に溶媒としてナフ タレンを用いたときの結果はFig.12のようになる。こ の場合の収率は, 無触媒の場合 (破線) と比較すると, 反応時間が 10 分以内でやや高い程度であるが，それ以 降では両者の差は次第に大きくなり，触媒存在下にお ける収率はテトラリン／水素系（Fig.4(a),(b)）および

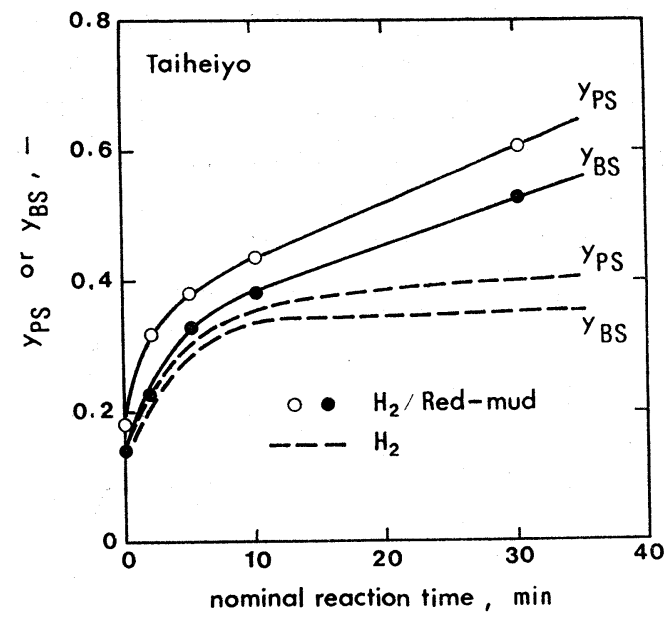

Fig. 11 Effect of red-mud catalyst on "direct (II) and indirect (III) transfer" without solvent at hydrogen pressure of 10.1 MPa and 723K

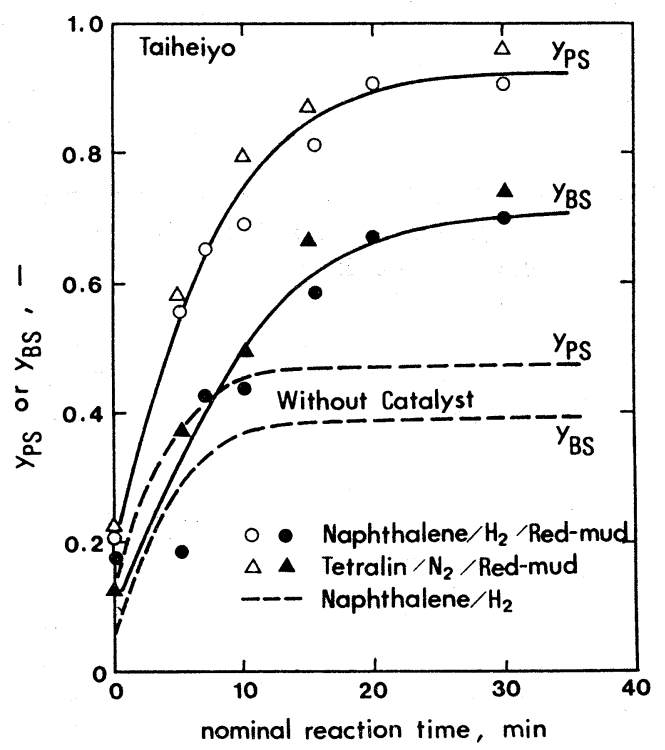

Fig. 12 Effect of red-mud catalyst on "direct (II) and indirect (III) transfer" with naphthalene at $10.1 \mathrm{MPa}$ and $723 \mathrm{~K}$

テトラリン/窒素／触媒系 (Fig.9) の場合をわずかに 下回る程度に増加する。もし，この収率の増加が溶媒 （ナフタレン）による溶解水素の増加に起因するもの とすれば，無触媒の場合でも高い収率が得られるはず であるし，また溶解水素の直接移動（II）に対する触媒 効果によるものであれば，テトラリン／水素系执よび テトラリン/水素／触媒系に拈けるテトラリン消費量 
（Fig.10)に差がでるはずである。したがって，上の結 果は, 触媒の効果が水素によるナフタレンのテトラリ ンへの転化，すなわち水素の間接移動(III)を促進する ことを示唆している。一方，ナフタレンのテトラリン への転化を測定した結果，テトラリンは反応時間30分 で数\%以下しか実測されなかった。さらに，テトラリ ン/水素/触媒系に和けるテトラリン消費速度はテト ラリン／水素系の場合と等しいので，これらの結果は ナフタレンの接触水添速度 (再生速度) がテトラリン の脱水素反応速度に比べて小さいことを示している。 したがってテトラリン大過鄱の場合にはテトラリン消 費による水素移動( IN)の寄与が，ナフタレンを経由す るガス相水素の移動 (III)よりも大きいのに対し，ナフ タレン大過鄱の場合には，ナフタレンとガス相水素か らテトラリンを生成する反応速度に対するナフタレン 濃度項の効果によって，初期反応進行に必要最小限の テトラリンを生成し，この間接移動(III)の寄与が直接 移動（II)上りも大きいと考光れば，以上の結果を矛盾 なく説明できよう。このように，触媒の直接移動（II） 飞対する効果はピリジンおよびベンゼン可溶分収率の 変化から評価される反応初期過程 (Coal $\rightarrow$ Preasphaltenes $\rightarrow$ Asphaltenes）に怙いては小さいが，反応後 期過程 (Asphaltenes $\rightarrow$ Oils) 飞执いて，とくに，反 応初期に生成したオイル分から水素供与性溶媒を生成 させる際には重要となろう。

以上のような各水素移動過程の総括液化反応に対す る寄与の相対的大ささは, 反応温度や時間, 水素圧力, 溶媒中の水素供与性成分濃度, 石炭組成拉よび触媒な ぞが異なれば当然複雑に変化すると考兄られる。既往

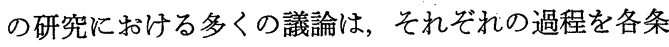
件下で強調した結果と理解でき，今後とも同様の実測 值を蓄積して，定量的に把握することが望をれる。

\section{4. 結 論}

内容積 $27 \mathrm{~cm}$ の急速昇温小型オートクレーブ反応装置 に颃いて，打もに太平洋炭の液化反応実験を $723 \mathrm{~K}$, $10.1 \mathrm{MPa}$ で行い，液化初期反応過程での 水素移動に ついて検討した。その結果，本実験範囲で次のような ことが明らかになった。

1）触媒を用いない場合, ガス相あるいは溶解水素 の直接移動（II）の寄与は活とんどない。また，溶 媒の石炭粒子分散効果は小さい。さらに，溶媒と してテトラリンを用いた場合，シャトリングによ る水素移動（I ）の寄与率は次第に減少し, その減 少割合は炭種によって異なる。

2）触媒は，シャトリング(I)やテトラリンによる
ドネーション(N)および水素の直接移動（II）には ほとんど影響を与えず，水素の間接移動（III）に最 も大きな効果をもつ。

\section{文献}

1) 石井忠雄, 前河涌典, 武谷 愿, 化学工学, 29 , 988 (1965)

2）千葉忠俊, 真田雄三，燃協誌，57，259（1978）

3）馬場有政，資源技術試験所報告，№.27，1（1955）

4) Brown, H.R. and Waters, P.L., Fuel, 45, 41 (1966)

5) Neavel, R.C., ibid., 55, 237 (1976)

6) Whitehurst, D.D., Faracasiu, M., Mitchell, T.O. and Dickert, J. J. Jr., EPRI Report, AF-480, p. 8-20 (1977)

7) Whitehurst, D.D., Michell, T.O., Faracasiu, M. and Dickert, J.J. Jr., EPRI Report, AF-1298, Volume 2, 10-15 (1979)

8) Whitehurst, D.D. and Michell, T.O., Preprints of ACS Div. Fuel Chem., 21, (5), 127 (1976)

9) Gorin, E., "Chemistry of Coal Utilization" 2nd Suppl. Vol., Ed. Elliot, M.A., WileyInterscience, p.1862 (1981)

10) Longanbach, J.R., Droege, J.W. and Chauhan, S.P., Preprints of ACS Div. Fuel Chem., 24, (2), 52 (1979)

11) Furlong, L.E., Effron, E., Vernon, L.W. and Wilson, E.L., Chem. Eng. Progr., 72, (8), 69 (1976)

12) Maekawa, Y., Ishii, T. and Takeya, G., J. Chem. Eng. Japan, 10, (2), 101 (1977)

13) Guin, J.A., Tarrer, A.R., Lee, J.M., Lo, L. and Curtis, C. W., Ind. Eng. Chem. Proc. Des. Dev., 18, 371 (1979)

14) Guin, J.A., Tarrer, A.R., Prather, J.W., Johnson, D. R. and Lee, J. M., ibid., 17, 118 (1978)

15) Tsai, M.C. and Weller, S.W., Fuel Proc. Tech., 2, 313 (1979)

16) Rottendorf, H. and Wilson, M.A., Fuel, 59, 175 (1981)

17) Chow, C. K., ibid., 59, 1153 (1981)

18) Ueda, S., Nakata, Y., Yoshida, T. and Maekawa, Y., Proc., Int. Conf. on Coal Science, Düsseldorf, p. 380 (1981) 
19）守富 寛，黒氏昭仁，真田雄三，千葉忠俊，燃協

誌, 62, 199 (1983)

\title{
Hydrogen Transfer During Initial Stage of Coal Liquefaction
}

\author{
Hiroshi Moritomi, Hiroshi NAGAISHI, Masahiko NARUSE, \\ Yuzo SANADA and Tadatoshi CHIBA
}

(Coal Research Institute, Hokkaido University)

SYNOPSIS :-A series of coal liquefaction experiments were carried out to evaluate the individual contribution of hydrogen transfer processes to the overall extent of the reaction and to examine the effects of solvent and catalyst on the hydrogen transfer. The liquefaction was performed in a $27 \mathrm{~cm}^{3}$ rapid-heating micro-autoclave at $723 \mathrm{~K}$ and 10.1 $\mathrm{MPa}$ as a function of the reaction time using some the combinations of coal (Taiheiyo and Illinois No.6), gas atmosphere $\left(\mathrm{N}_{2}\right.$ and $\mathrm{H}_{2}$ ), solvent (naphthalene and tetralin) and catalyst (red-mud and Co-Mo).

Without catalyst little difference was observed between the yields of pyridineand benzene-solubles under nitrogen atmosphere and those under hydrogen atmosphere, suggesting that the direct transfer of gaseous hydrogen to the coal hardly occurs.

Also, little effect of coal particles dispersion by solvent was detected on the hydrogen transfer. When tetralin was used as the hydrogen-donor solvent, the contribution of the hydrogen shuttling to the overall transfer decreased with time and the rate of the decrease differed with coal nature. On the other hand, the tetralin consumption in $\mathrm{N}_{2}, \mathrm{H}_{2}$ and $\mathrm{H}_{2} /$ catalyst systems remained unchanged and the yields of pyridine-and benzene-solubles in naphthalene/ $\mathrm{H}_{2} /$ catalyst system were almost the same as those for above systems. It was therefore concluded that the catalyst was most effective on the indirect transfer of gaseous hydrogen through the coal-derived liquids and/or naphthalene during the initial stage.

\section{Key Words}

Coal liquefaction, Hydrogen transfer, Hydrogen consumption, Donor solvent, Catalysts 